\title{
Enzyme-linked immunosorbent assay for the serodiagnosis of toxoplasmosis
}

\author{
D MILATOVIĆ AND I BRAVENY
}

From the Institute of Medical Microbiology, Technical University Munich (Klinikum r.d. Isar), Ismaningerstr 22, 8000 Munich 80, West Germany

SUMmARY The enzyme-linked immunosorbent assay (ELISA) for toxoplasmosis proved as sensitive as the dye test and indirect haemagglutination (IHA). The reproducibility of end-point titres was better than that of the extinction values obtained from a single serum dilution. In a comparison of 152 sera, ELISA was found to correlate better with IHA than with the dye test. The use of ELISA for routine serology and population screening is discussed.

Since its introduction by Engvall and Perlmann, ${ }^{1}$ the enzyme-linked immunosorbent assay (ELISA) has been used to detect antibodies in a variety of infectious diseases. Several investigators have evaluated ELISA for the serodiagnosis of toxoplasmosis. ${ }^{2-7}$ Different authors have found the correlation with the indirect immunofluorescence (IIF) and dye test, and with indirect haemagglutination (IHA), to vary, so that the value of ELISA in toxoplasmosis serology has been difficult to assess. Our particular interest was whether ELISA might replace one of the established methods, and whether it could be used as a screening test.

\section{Material and methods}

\section{ANTIGEN}

Toxoplasma gondii cells (RH strain) were harvested from the peritoneal exudate of infected mice and filtered (Schleicher u. Schüll, Dassel, No. 1450). The cells were collected by centrifugation at $3000 \mathrm{~g}$ and washed three times in phosphate buffered saline (PBS). The sediment was resuspended in $4 \mathrm{ml}$ PBS and sonicated (300 S Ultrasonic, Braun Melsungen) at $4{ }^{\circ} \mathrm{C}$ for 7 minutes. After centrifugation at $10000 \mathrm{~g}$ for 30 minutes, the supernatant (soluble antigen) was stored in aliquots in liquid nitrogen.

\section{SERA}

Sera submitted for toxoplasmosis serology are examined routinely by the dye test, complement fixation test (CFT), and indirect haemagglutination (IHA); 152 serum samples showing different serological patterns were examined by the micro-

Received for publication 7 February 1980
ELISA technique. These sera were divided into three groups on the basis of the dye test and CFT titres, as follows:

Group 1 dye test $<1 / 16$ (negative)

Group 2 dye test titre between $1 / 16$ and $1 / 1000$, CFT titre $\leqslant 1 / 10$ (intermediate titres)

Group 3 dye test titre $\geqslant 1 / 1000$, CFT titre $>1 / 10$ (high titres)

CONJUGATE

Commercially available horseradish peroxidase conjugated sheep antihuman globulin (Institut Pasteur) was used for the ELISA.

SUBSTRATE

This was prepared as follows: $80 \mathrm{mg}$ of 5-aminosalicylic acid were dissolved in $100 \mathrm{ml}$ of distilled water $\left(80^{\circ} \mathrm{C}\right)$. Immediately before use, the $\mathrm{pH}$ was brought to 6.0 with $1 \mathrm{~N} \mathrm{NaOH}$. Nine parts of the above solution were mixed with one part of $0.05 \%$ $\mathrm{H}_{2} \mathrm{O}_{2}$.

MICRO-ELISA

The test was carried out essentially as described by Voller et al. ${ }^{6}$ Flat-bottomed polystyrene microtitre plates (Cooke M 29 A, Dynatech Laboratories) were coated with $0.15 \mathrm{ml}$ toxoplasma antigen, diluted to optimal concentration in $0.05 \mathrm{M}$ carbonate buffer (pH 6.0), and left overnight at $+4^{\circ} \mathrm{C}$. Before use the plates were washed again, and $0.15 \mathrm{ml}$ of the conjugate, diluted in PBS/Tween, was added to the wells. The plates were incubated for 1 hour at $37^{\circ} \mathrm{C}$ and then washed as before. Finally, the wells were filled with $0.15 \mathrm{ml}$ of the substrate, and the plates were left at room temperature for 30 minutes. The enzyme reaction was stopped by adding $0.05 \mathrm{ml} 1 \mathrm{~N}$ 
$\mathrm{NaOH}$ to each well, which was then read with a spectrophotometer (Titertek Multiskan, Flow Laboratories) at $450 \mathrm{~nm}$. The last serum dilution yielding a higher extinction value than the 1 in 16 dilution of the negative control serum was regarded as the end-point. Ninety additional sera were also tested at a 1 in 100 dilution; the results are expressed as extinction values $\left(\mathrm{E}_{450}\right)$.

\section{PRELIMINARY TEST}

The optimal antigen and conjugate concentration was established by chess-board titration against a known positive and negative reference serum. The dilution showing the greatest difference between extinction values of the positive and negative sera was used for the assay.

\section{Results}

RELATIONSHIP OF ELISA TITRES TO E450

VALUES OF A SINGLE SERUM DILUTION

In a preliminary study the ELISA end-point titres of 67 sera were compared with the $E_{450}$ values of a 1 in 100 dilution of the same sera. The results are plotted in Figure 1. The correlation coefficient of $0.92(\mathrm{P}<0.001)$ indicated that the antibody titre of a serum could be determined from the $E_{450}$ value of the 1 in 100 dilution.

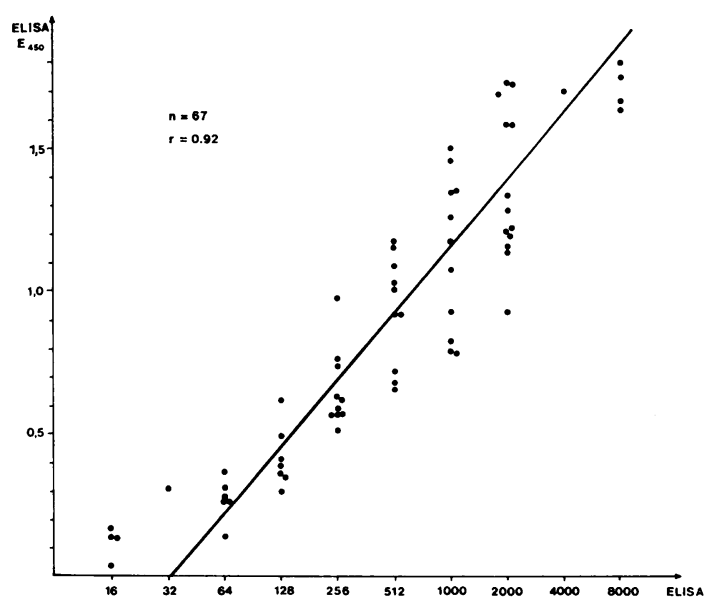

Fig. 1 Relationship of the ELISA end point titres to the $E_{450}$ values at a 1 in 100 dilution in 67 serum samples.

\section{REPRODUCIBILITY}

The reproducibility of the ELISA was tested by performing 10 assays on different days with the positive reference serum. The titre end-points and $E_{450}$ values of the 1 in 100 serum dilution were determined.
From the $\mathrm{E}_{450}$ values the titres were also calculated using the regression line in Figure 1. All 10 tests gave end-points of 1/2000. The $E_{450}$ values of the 1 in 100 serum dilution ranged from $1 \cdot 143$ to 1.59 . The calculated titres differed only by \pm 1 twofold dilution.

The positive reference serum was also tested in a 1 in 100 dilution in each well of two microtitre plates on the same day. The arithmetic mean of the $E_{450}$ values of each plate was taken and $\pm 10 \%$ was allowed for experimental error. Only two readings exceeded the $\pm 10 \%$ limit on plate I, whereas 19 readings did so on plate II.

\section{COMPARISON OF ELISA, DYE TEST, AND IHA} TITRES

End-point titres of 152 serum samples obtained by the ELISA technique were compared with the dye test and IHA titres (Figs 2 and 3). With a range of \pm 1 dilution step there was an agreement of $78 \%$ between ELISA and the dye test and of $89 \%$ between ELISA and IHA.

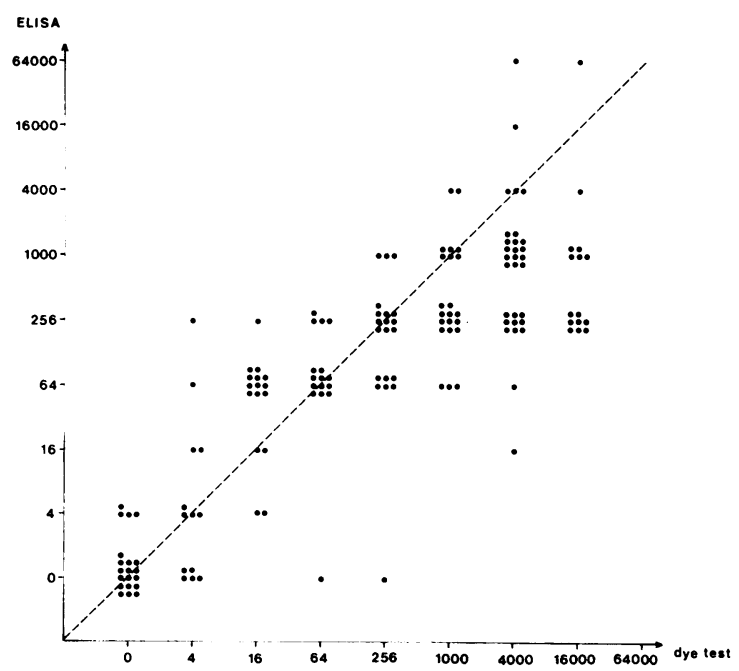

Fig. 2 Comparison of ELISA and dye test titres in 152 sera.

Four sera $(2.6 \%)$ which were negative in the dye test $(<1 / 16)$ gave positive results with ELISA, yielding titres of $1 / 256,1 / 64$, and $1 / 16$ twice. The same percentage of sera gave false negative reactions in ELISA.

In group 1 sera, which were nonreactive in the dye test and CFT, ELISA correlated well with the dye test $(94 \%)$ and with IHA $(88 \%)$. Group 2 sera, giving intermediate titres, correlated well with ELISA and the dye test in $90 \%$ and with ELISA and IHA in $87 \%$ of cases. In the high-titre group 3 sera, 


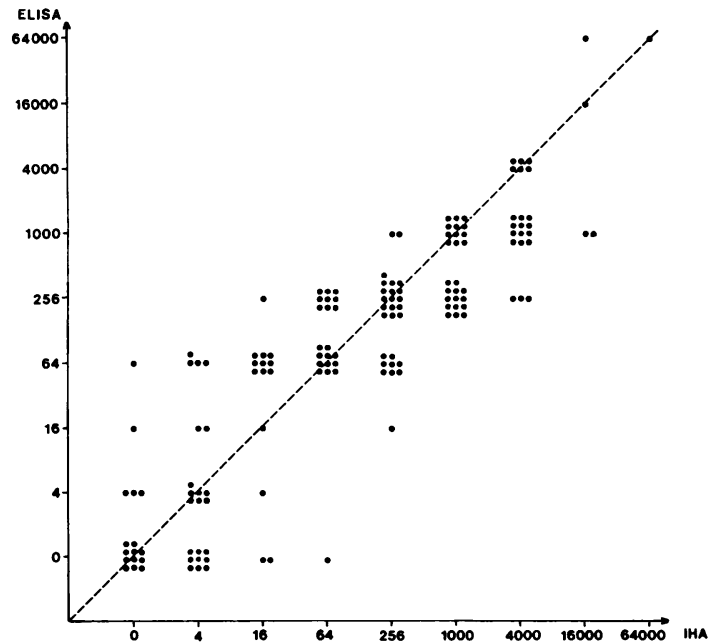

Fig. 3 Comparison of ELISA and IHA titres in 152 sera.

however, ELISA titres were much lower than dye test titres. The dye test agreed with ELISA in only $53 \%$ of cases, in contrast to a good correlation $(89 \%)$ between ELISA and IHA (Table).

\section{Discussion}

The reproducibility of the micro-ELISA for toxoplasmosis was found to be satisfactory. Determination of the end-point was more accurate than measurement of $E_{450}$ values of a single 1 in 100 serum
Percentage of agreement within \pm 1 dilution step between ELISA and the dye test and between ELISA and IHA for sera grouped according to their dye test and CFT titres

\begin{tabular}{llll}
\hline Group $*$ & \multicolumn{4}{l}{ Percentage of agreement between: } \\
\cline { 2 - 4 } & ELISA/dye test & ELISA/IHA & $n$ \\
\hline All sera & 77 & 89 & 152 \\
1 & 94 & 88 & 47 \\
2 & 90 & 87 & 62 \\
3 & 53 & 89 & 33 \\
\hline
\end{tabular}

*1 = negative, $2=$ intermediate titres, $3=$ high titres.

dilution. As there are considerable variations in the quality of microtitre plates, this source of error would play a more important role in determining the $\mathbf{E}_{450}$ value than the end-point titre.

The present investigation has shown that the antibody titre obtained by ELISA correlates better with IHA than with the dye test titres, as also described by Voller et al. ${ }^{6}$ This seems to be based on the fact that ELISA and IHA utilise soluble antigen, whereas the dye test and IIF are performed with whole intact parasites. In the early stages of the infection, antibodies to the cell wall are the first to be formed. The discrepancy between ELISA and the dye test is, therefore, particularly marked in sera presenting higher dye test titres. Similar results have been reported by Voller et al. ${ }^{6}$ and also by Ruitenberg and van Knapen, ${ }^{5}$ who compared ELISA and IIF. Other authors, ${ }^{3}{ }^{7}$ however, claim a close correlation between ELISA and IIF. These differing results may be due to a lack of standardisation of the ELISA

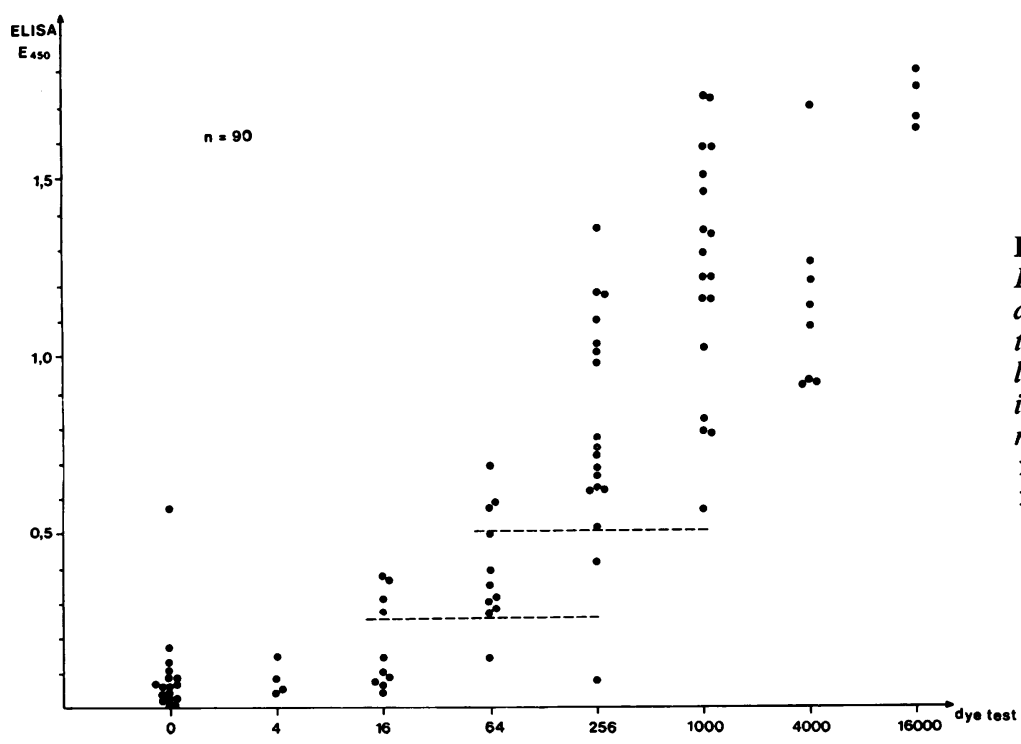

Fig. 4 Relationship of the ELISA $E_{450}$ values at a 1 in 100 serum dilution to the corresponding dye test titres of 90 sera. The significance limits of extinction values to be used in a screening test for toxoplasmosis might be set at $0 \cdot 25$ (dye test titre $>1 / 16)$ or at 0.5 (dye test titre $>1 / 64)$. 
method, in particular in the preparation and purification of the antigen.

The question arises whether ELISA could replace one of the established tests in toxoplasmosis serology. The sensitivity of ELISA is comparable to that of the dye test and IHA but is not higher. Since ELISA as used here does not discriminate between sera with intermediate and high dye test titres it cannot be used as an alternative to the dye test or IIF.

ELISA and IHA seem to measure the same type of antibodies. Each method has its advantages. IHA can be performed easily and quickly, and no additional equipment is required. For testing large numbers of sera, ELISA has the advantage of possible mechanisation.

ELISA may be useful in seroepidemiology. In Fig. 4, the ELISA E 450 values of 90 sera are plotted against the corresponding dye test titres. On the basis of the interpretation of the significance limits of dye test titres $(>1 / 16$ or $>1 / 64)$, a certain $E_{450}$ value must be set for the detection level. The examples in Fig. 4 show that a small percentage of false negative $(2-3 \%)$ and false positive $(4-6 \%)$ results is unavoidable.

We consider that ELISA brings no clear advantage in the routine serological diagnosis of toxoplasmosis but would be useful in population screening if the method were standardised.

\section{References}

${ }^{1}$ Engvall E, Perlmann P. Enzyme-linked immunosorbent assay (ELISA). Quantitative assay of immunoglobulin G. Immunochemistry $1971 ; 8: 871-4$.

${ }^{2}$ Bout D, Dugimont JC, Farag H, Capron A. Le diagnostic immunoenzymologique des affections parasitaires. Immunoenzymologie quantitative (ELISA). Lille Med 1975;20:561-6.

${ }^{3}$ Camargo ME, Ferreira AW, Mureo JR, Takiguti CK, Nakahara OS. Immunoglobulin $G$ and immunoglobulin $M$ enzyme-linked immunosorbent assay and defined toxoplasmosis serological patterns. Infect Immun 1978; $21: 55-8$.

+ Denmark JR, Chessum BS. Standardization of enzymelinked immunosorbent assay (ELISA) and the detection of toxoplasma antibody. Med Lab Sci 1978;35:227-32.

${ }^{5}$ Ruitenberg EJ, van Knapen F. The enzyme-linked immunosorbent assay and its application of parasitic infections. $J$ Infect Dis 1977;136 Suppl:267-73.

${ }^{6}$ Voller A, Bidwell DE, Bartlett A, Fleck DG, Perkins M, Oladehin B. A microplate enzyme-immunoassay for toxoplasma antibody. J Clin Pathol 1976;29:150-3.

7 Walls KW, Bullock SL, English DK. Use of the enzymelinked immunosorbent assay (ELISA) and its microadaptation for the serodiagnosis of toxoplasmosis. J Clin Microbiol 1977;5:273-7.

Requests for reprints to: Professor Dr I Braveny, Inst. f. Med. Mikrobiologie und Hygiene der Technischen Universität München, 8000 München 80, Trogerstrasse 9, West Germany. 